\title{
EFFECT OF CELLULAR GROWTH ON PROTEIN METABOLISM IN CHICKEN EMBRYO FIBROBLASTS*
}

by

\author{
TONNI BALLE and KLAVS B. HENDIL
}

August Krogh Institute, University of Copenhagen

13 Universitetsparken, DK-2100 Copenhagen $\varnothing$

*This paper is dedicated to Professor Heinz Holter on the occasion of his 80th anniversary

Keywords: Protein turnover, growth regulation, fibroblasts

Protein synthesis in cultures of chick embryo fibroblasts was measured as the incorporation of ${ }^{3} \mathrm{H}$-leucine into trichloroacetic acid-insoluble material. Intracellular protein degradation was measured as the release of trichloroacetic acid-soluble radioactivity after pre-labelling cell protein with ${ }^{3} \mathrm{H}$-leucine.

The rate of degradation increased whereas the rates of protein synthesis and cell growth decreased as the cultures approached confluence in growth medium with $1 \%$ serum. The rate of protein degradation was reduced when the serum concentration in the culture medium was increased, and the effect of increasing serum concentration was higher in dense than in sparse cultures. There were linear correlations between the rate of protein turnover and culture density, but the slope was lower in medium with $4 \%$ chicken serum than in medium with $1 \%$ chicken serum.

Cell growth was measured as the incorporation of ${ }^{3} \mathrm{H}$-thymidine into DNA. The correlation between culture density and thymidine incorporation was sigmoid. Density-dependent inhibition of growth was less complete in medium with $4 \%$ serum than in $1 \%$ serum. The correlations between protein degradation and growth rate were also sigmoid and seemed to differ in media with $1 \%$ and $4 \%$ serum.

\section{INTRODUCTION}

The mass of a tissue is maintained by a delicate balance between proliferation and loss of its constituent cells. This balance is upset in cancers and in tissue-wasting diseases. The regulation of cell proliferation in the intact organism is poorly understood but cell cultures provide a simpler system for the study of cellular growth control. Apart from salts and nutrients, avain and mammalian cells in culture need hormones and peptide growth-factors for proliferation (11). These are usually provided as serum. The cells also need to attach to and spread on an appropriate surface (7). Perhaps for that reason the growth rate of normal cells diminishes when they reach a certain culture density. This phenomenon is called "density-dependent inhibition of growth" (18). The requirements for both growth factors and cell spreading are reduced in transformed, tumorigenic cells $(11,15)$.

Growth is the difference between synthesis and degradation of cell constituents, primarily protein. Several studies have shown that the reduction in cell proliferation in density-inhibited cultures of normal cells is attained by a decrease in the rate of protein synthesis and an increase in the rate of protein degradation $(3,5$,

Abbreviations: PBS = phosphate buffered saline; TCA = trichloroacetic acid 
$10,13,19)$. Transformed cells, in contrast, fail to increase the degradation on their intracellular protein and the resulting imbalance between synthesis and degradation may account for their continued proliferation where normal cells become quiescent $(4,9,12)$. However, growth regulation in normal cells may not always be associated with changes in protein degradation. Thus CASTOR (3) measured a faster protein turnover in quiescent human fibroblasts, whereas BRADLEY (2) found no difference in protein degradation between proliferating and densityinhibited cultures of the same cell line. For chicken embryo fibroblasts WEBER (20) and HENDIL (9) found equal protein degradation rates in growing and in density-inhibited cells, whereas GOLDBERG and ST. JOHN (8) quote unpublished results showing an increase in protein degradation in quiescent cultures of the same cell type.

Conceivably, these conflicting results originate in differences in experimental conditions. Here we show that the magnitude of the enhancement of intracellular protein degradation in density-inhibited chicken fibroblasts is reduced at high concentration of serum in the growth medium.

\section{MATERIALS AND METHODS}

\subsection{Materials}

Sera were obtained from Gibco-Biocult, tryptose phosphate broth was from Difco, and amino acids were from British Drug Houses. Methotrexate was from American Cyanamid and all other biochemicals were from Sigma. $\mathrm{L}-\left[4,5-{ }^{3} \mathrm{H}\right]$ leucine and [methyl- ${ }^{3} \mathrm{H}$ ] thymidine were purchased from Amersham.

The growth medium was Eagle's Minimal Essential Medium with Earle's salts. It was kept in equilibrium with a humidified atmosphere of $5 \% \mathrm{CO}_{2}$ and $95 \%$ air at $37^{\circ} \mathrm{C}$. The medium also contained non-essential amino acids (6), tryptose phosphate broth $(2 \%)$, penicillin $\mathrm{G}(100$ $\mathrm{U} / \mathrm{ml})$, streptomycin sulphate $(100 \mu \mathrm{g} / \mathrm{ml})$, and chicken serum in varied concentrations.

PBS, as used here refers to a solution which contains: $137 \mathrm{mM}-\mathrm{NaCl}, 2.7 \mathrm{mM}-\mathrm{KCl}, 4.1 \mathrm{mM}$ $\mathrm{Na}_{2} \mathrm{HPO}_{4}$ and $0.73 \mathrm{~mm}-\mathrm{KH}_{2} \mathrm{PO}_{4}$.

\subsection{Methods}

\subsubsection{Cell cultures}

Primary cultures of chick embryo fibroblasts were prepared from 10 days old white leghorn embryos. Minced leg muscles from each embryo were incubated for $30 \mathrm{~min}$ at $37^{\circ} \mathrm{C}$ in $5 \mathrm{ml} 0.05 \%$ trypsin ("1:250", Difco) in PBS. Five milliliter growth medium with $10 \%$ calf serum was added, and the remaining tissue clumps were broken up by repeated sucking and reexpelling through a 80 -gauge needle. The cells were then centrifuged at $200 \times \mathrm{g}$ for $5 \mathrm{~min}$, whereupon they were resuspended in culture medium with $1 \%$ chicken serum and distributed with $10 \mathrm{ml}$ and $5 \times 10^{6}$ cells per $90 \mathrm{~mm}$ petridish (Nunc).

These primary cultures were grown at $37^{\circ} \mathrm{C}$ for 3-4 days before they were treated with $0.05 \%$ trypsin for $5-15 \mathrm{~min}$ at $37^{\circ} \mathrm{C}$. The cells were then suspended in growth medium containing $10 \%$ calf serum, centrifuged and reseeded, usually in $58 \mathrm{~mm}$ petridishes (Nunc) with $4 \mathrm{ml}$ growth medium and various amounts of serum and cells. These dishes were used for experiments.

\subsubsection{Incorporation of ${ }^{3} \mathrm{H}$-leucine}

The cells were incubated in $4 \mathrm{ml}$ fresh growth medium with $2 \mathrm{mM}-\mathrm{L}\left[4,5 \cdot{ }^{3} \mathrm{H}\right] \mathrm{leucine}(0.5 \mathrm{Ci} /$ $\mathrm{mol}$ ). The radioactive medium was aspirated 1 hour later, and the dishes were rinsed 4 times in icecold PBS in less than $15 \mathrm{sec}$. The cultures were then extracted with $2 \times 5 \mathrm{ml} 0.2 \mathrm{M}$-perchloric acid, each time for $20 \mathrm{~min}$ at $4{ }^{\circ} \mathrm{C}$. The acid extract was counted directly whereas the precipitate remaining in the petridish was dissolved in 1-2 $\mathrm{ml}$ of reagent $\mathrm{C}$ (14) before a sample was taken for liquid scintillation counting.

\subsubsection{Protein degradation}

The cultures were labelled by incubation with ${ }^{3} \mathrm{H}$-leucine as detailed in the legends, whereupon they were washed by $3 \times 6 \mathrm{ml}$ PBS with $0.6 \mathrm{mM}$ unlabelled leucine. The cells were then incubated in $9 \mathrm{ml}$ growth medium with $4 \mathrm{mM}$ unlabelled leucine. One milliliter samples of medium were withdrawn from the cultures at intervals, and the cultures were finally rinsed 4 times in PBS and dissolved in 2 or $4 \mathrm{ml}$ of reagent $\mathrm{C}$ (14). Total and TCA-soluble radioactivity in 
samples of medium and cells was determined as previously described (9). The rate of protein degradation was calculated from the release of TCA-soluble radioactivity. It is given as percent of initially incorporated radioactivity released per unit time.

\subsubsection{Incorporation of ${ }^{3} \mathrm{H}$-thymidine}

Growth media used for these experiments were supplemented with glycine and hypoxanthine to $100 \mu \mathrm{M}$ and $300 \mu \mathrm{M}$, respectively. Labelling was initiated by the addition of $200 \mu 1$ of $2 \times 10^{-4} \mathrm{M}$-methotrexate and $2 \times 10^{-4} \mathrm{M}{ }^{3} \mathrm{H}$-thymidine $(100 \mathrm{Ci} / \mathrm{mol})$ to each culture with $9 \mathrm{ml}$ growth medium. After 90 minutes the cultures were washed in succession with $3 \times 6 \mathrm{ml}$ icecold PBS, $2 \times 3 \mathrm{ml} 4 \%$ TCA, and $2 \times 3 \mathrm{ml}$ ethanol before they were dried. The cell residue was dissolved in $2 \mathrm{ml} 0.1 \mathrm{M}-\mathrm{NaOH}$ and $0.4 \mathrm{ml}$ hereof was hydrolyzed at $100^{\circ} \mathrm{C}$ for $15 \mathrm{~min}$ with $100 \mu \mathrm{l}$ $3 \mathrm{M}-\mathrm{HCl}$ before counting.

\subsubsection{Other methods}

Cells were counted in a hemocytometer. Protein was determined as described by OYAMA and EAGLE (14) with bovine serum albumin as a standard.

Radioactivity was determined by liquid scintillation counting in $10 \mathrm{ml}$ cocktail which contained per litre: toluene $634 \mathrm{ml}$, Triton X-100 $316 \mathrm{ml}, 0.5 \mathrm{M}-\mathrm{HCl} 50 \mathrm{ml}, 2,5$-diphenyloxazole $5.2 \mathrm{~g}$ and 4-bis-(5-phenyloxazolyl-2)-benezene $0.1 \mathrm{~g}$.

\section{RESULTS}

\subsection{Assessment of synthesis and degradation of intracellular protein}

Figure 1 shows that the rate of incorporations of ${ }^{3} \mathrm{H}$-leucine into protein increases with the concentration of leucine in the medium until it reaches a plateau at leucine concentrations above $2 \mathrm{mM}$. The amount of intracellular ${ }^{3} \mathrm{H}$ leucine continues to increase with leucine concentration beyond $8 \mathrm{~mm}$. The plateau in leucine incorporation is therefore not caused by saturation of the transport system. Instead it reflects

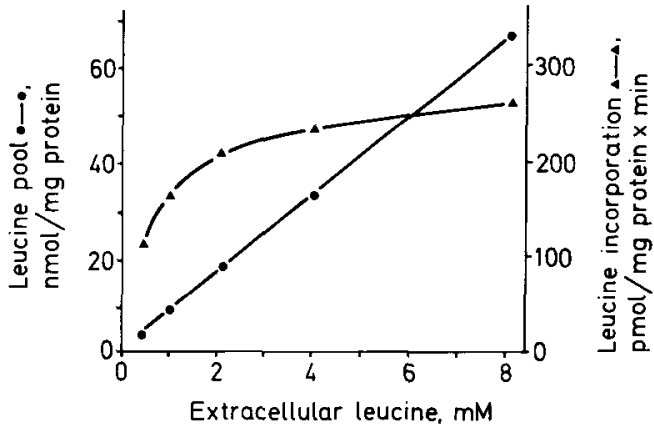

Figure 1. Effect of extracellular ${ }^{3} \mathrm{H}$-leucine concentration on incorporation and pool size of intracellular ${ }^{3}$ H-leucine.

Petridishes $(58 \mathrm{~mm})$ were inoculated with $5 \times 10^{6}$ chick embryo fibroblasts in $4 \mathrm{ml}$ growth medium with $1 \%$ chicken serum. Four days later the cells were labelled for one hour with fresh medium containing ${ }^{3} \mathrm{H}$-leucine $(1 \mu \mathrm{Ci} / \mathrm{ml})$ and unlabelled leucine as indicated. Incorporation into perchloric acid insoluble

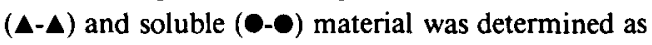
described in Methods.

the true rate of leucine incorporation because the intracellular pool of leucine is flooded so that the specific radioactivity of intracellular and extracellular leucine are identical. The rate of ${ }^{3} \mathrm{H}$-leucine incorporation was linear with time for at least 3 hours in medium with $2 \mathrm{~mm}$-leucine (data not shown). Other experiments showed that the rate of cell growth was unaffected by leucine in the concentration range 0.4 to $4 \mathrm{mM}$ (data not shown). Protein synthesis was therefore measured as the incorporation of labelled leucine into TCA-insoluble material from medium with 2 mM-leucine.

Protein degradation was measured as the release into growth medium of TCA-soluble radioactivity from ${ }^{3} \mathrm{H}$-leucine labelled cells. This release was reduced in media with leucine concentrations below $0.2 \mathrm{~mm}$, probably due to reincorporation of ${ }^{3} \mathrm{H}$-leucine generated by protein degradation (data not shown). Consequently, 4 mM-leucine was added to the media used for assessment of protein degradation in order to suppress reincorporation of labelled leucine. 


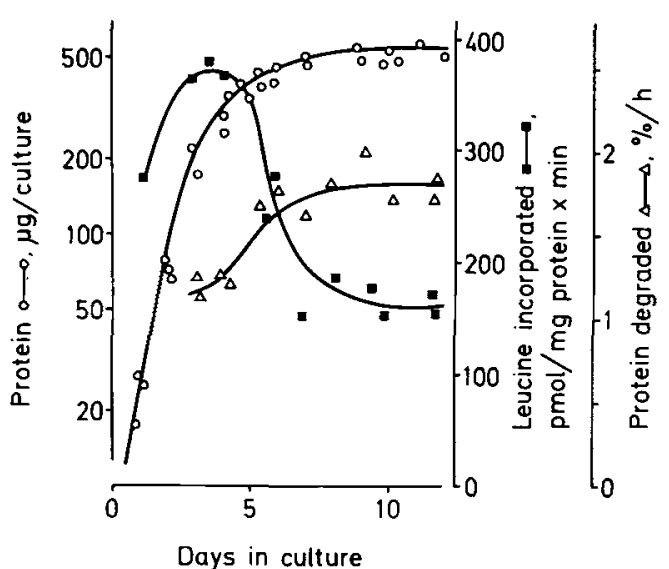

Figure 2. Protein metabolism during the growth cycle.

Petridishes $(58 \mathrm{~mm})$ were inoculated with $1 \times 10^{5}$ chick embryo fibroblasts in $4 \mathrm{ml}$ growth medium with $1 \%$ chicken serum. This medium was changed every second day. Duplicate dishes were taken at intervals for determination of protein (o-o, log scale) and of ${ }^{3} \mathrm{H}$-leucine incorporation into TCA-insoluble material ( - ), as described in Methods. For determination of protein degradation the cells were labelled for 50 hours in growth medium cointaining $0.4 \mathrm{~mm}-{ }^{3} \mathrm{H}$-leucine $(2.5$ $\mathrm{Ci} / \mathrm{mol}$ ) and subsequently washed with PBS and incubated in non-radioactive medium for 15 hours. The release of trichloroacetic acid-soluble radioactivity into the medium was then measured during a 6 hours period $(\Delta-\Delta)$ as described in Methods. Each point represents the mean of duplicate samples. Observations are pooled from 3 experiments.

\subsection{Protein metabolism during growth and quiescence}

Sparsely seeded cultures of chicken embryo fibroblasts grow with a population doubling time of 18 hours in medium with $1 \%$ chicken serum. The growth rate decreases as the cultures approach a saturation density of 500-600 $\mu \mathrm{g}$ protein per dish when the medium is changed every second day. Figure 2 shows that cessation of cell growth in dense cultures is due to both a decrease in the rate of protein synthesis and an increase in protein degradation. The cells remained viable at their saturation density and the rates of protein synthesis and degradation in dense cultures were constant for at least 6 days after cessation of growth (Figure 2).

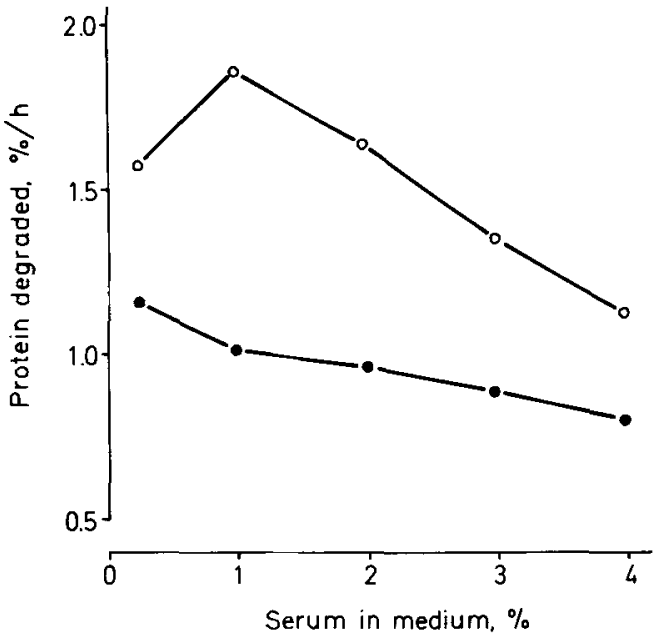

Figure 3. Effect of serum concentration on intracellular protein degradation.

Petridishes $(58 \mathrm{~mm})$ were inoculated with $2 \times 10^{5}$ chick embryo fibroblasts in $4 \mathrm{ml}$ growth medium with $1 \%$ chicken serum. Two days later the cells were labelled in medium with $0.4 \mathrm{~mm}^{-}{ }^{3} \mathrm{H}$-leucine $(5 \mathrm{Ci} / \mathrm{mol})$ for 18 hours. Protein breakdown was then measured during a 24 hours period as described in Methods, either in medium with the indicated serum concentra-

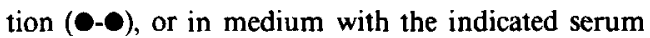
concentration plus an overlay of unlabelled chick embryo fibroblasts (o-0). The number of cells added to each $20 \mathrm{~cm}^{2}$ petridish was one half from a culture, which had been grown to confluence at the serum concentration shown on the abcissa but in a $60 \mathrm{~cm}^{2}$ petridish. Degradation was measured in the period 6-24 hours after labelling. Each point represents the mean of duplicate cultures which deviated less than $6 \%$ from each other. The experiment shown is representative for a total of 3 experiments.

\subsection{The effect of serum on protein degradation}

Figure 3 shows that the rate of protein degradation in sparsely seeded, exponentially growing cell cultures decreases with increasing concentration of serum in the growth medium. Protein degradation in quiescent, density-inhibited cultures was investigated by addition to labelled, sparse cultures of unlabelled cells to increase the total culture density to the saturation density. The saturation density of cultures increases with the serum concentration of the culture medium (11). Hence the number of cells necessary to 
cause growth inhibition is higher in medium with high serum concentration than in medium with low serum concentration. In the experiment shown (Figure 3) the cells added were from parallel cultures grown to their saturation density at the same serum concentration as that of the sparse cultures to which they were added. This ensured that the final cell density was sufficient to cause growth infibition at all serum concentrations employed. In cultures growth inhibited following this protocol the rate of protein degradation decreases as the serum concentration increases, except at serum concentrations below $1 \%$ (Figure 3). It is also evident that the difference in the rate of protein breakdown between sparse and dense cultures decreases as the serum concentration increases. This result suggests that the importance of protein degradation for growth control diminishes with increasing concentration of serum or, alternatively, that the density-dependent inhibition of growth becomes less complete at high serum concentrations so that the dense cultures in Figure 3 are only truly quiescent at low serum concentrations. To explore these possibilities we measured the rate of ${ }^{3} \mathrm{H}$-thymidine incorporation as a measure of growth rate and the rate of protein degradation in parallel cultures of varying densities, and at high and low serum concentration, respectively.

\subsection{Regulation of cell growth}

Chick fibroblasts were seeded with various culture densities in growth medium with either $1 \%$ or $4 \%$ serum. The rate of synthesis of endogenous thymidine varies with cell growth rate (1) and this endogenous thymidine decreases the specific radioactivity of intracellular ${ }^{3} \mathrm{H}$-thymidine. Therefore, the cellular synthesis of thymidine was blocked with methotrexate during the labelling period. This procedure ensures that the specific activity of intracellular thymidine triphosphate is equal to the specific activity of thymidine added to the medium and thus constant under all experimental conditions $(1,17)$. Experiments that are not presented here showed that the incorporation of ${ }^{3} \mathrm{H}$-thymidine was linear with time for at least 4 hours under all conditions used. Also, treatment of cells with

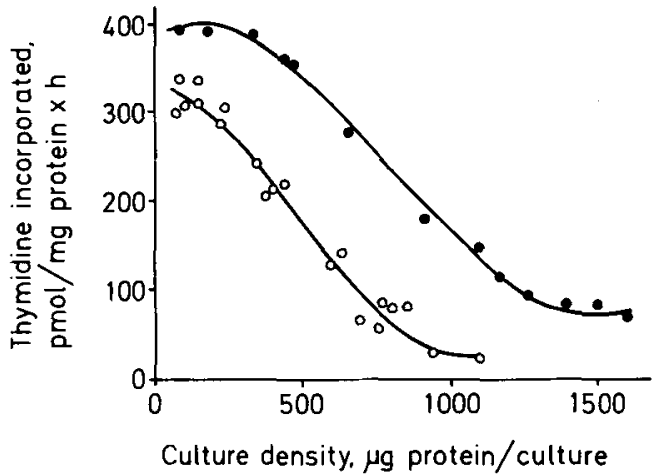

Figure 4. Effect of culture density on thymidine incorporation in medium with $1 \%$ or $4 \%$ chicken serum.

Fibroblast cultures were treated in parallel with those used for determination of protein breakdown (Figure 5). ${ }^{3} \mathrm{H}$-Thymidine incorporation was measured from 5 to $61 / 2$ hours after the last medium change. Curves are fitted by the method of least squares. $0-0$, $1 \%$ serum, $Y=330-74,7 \times 10^{-3} \mathrm{X}-713 \times 10^{-6} \mathrm{X}^{2}+$ $491 \times 10^{-9} \mathrm{X}^{3}, \mathrm{r}^{2}=0.95 ; \bullet-\bullet, 4 \%$ serum, $\mathrm{Y}=393+$ $150 \times 10^{-3} X-644 \times 10^{-6} X^{2}+268 \times 10^{-9} X^{3}, r^{2}=0.99$.

methotrexate did not influence their rate of protein degradation.

The correlation between thymidine incorporation (growth rate) and culture density is shown in Figure 4. Growth rate decreases almost linearly with culture density in $1 \%$ serum. At all culture densities cells grow faster in $4 \%$ serum than in $1 \%$ serum, and higher culture densities are attained. Figure 4 also shows that cells grown in $4 \%$ serum have no well defined saturation density since they continue to growth, albeit slowly, even in crowded cultures. Culture densities higher than those used here proved difficult to attain since very dense cell layers tend to retract and peel from the culture dishes.

\subsection{Protein degradation and growth rate}

The correlation between protein degradation and culture density is shown in Figure 5. The rate of protein metabolism increases linearly with culture density in both $1 \%$ and $4 \%$ serum. Serum inhibits intracellular protein degradation, except in very sparely seeded cultures.

The data in Figures 4 and 5 were fitted by polynomial and linear regressions, respectively. 


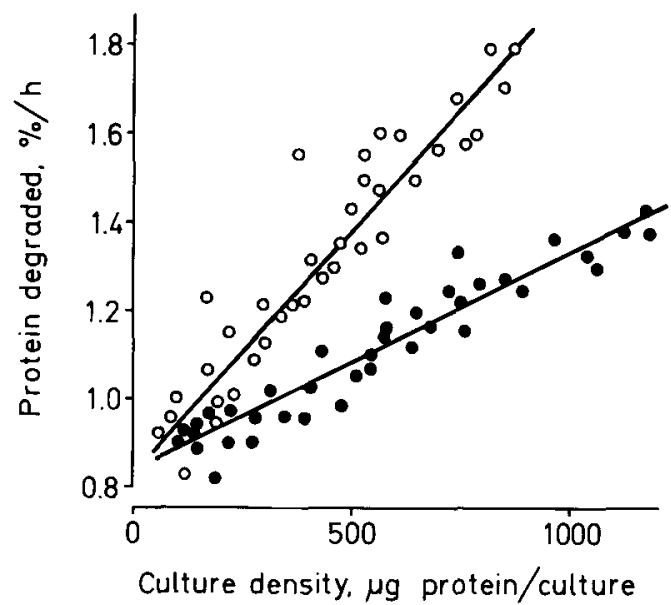

Figure 5. Effect of culture density on intracellular protein breakdown in medium with $1 \%$ or $4 \%$ chicken serum.

Tissue culture flasks $\left(180 \mathrm{~cm}^{2}\right)$ were inoculated with $5 \times 10^{6}$ chick embryo fibroblasts in $30 \mathrm{ml}$ growth medium. Two days later the cells were incubated in fresh medium with $0.4 \mathrm{mM}^{3}{ }^{3} \mathrm{H}$-leucine $(2.5 \mathrm{Ci} / \mathrm{mol})$ for 50 hours. The cells were then treated with trypsin and reseeded into petridishes with $4 \mathrm{ml}$ non-radioactive growth medium at densities ranging from $2 \times 10^{5}$ to $8 \times 10^{6}$ cells per $20 \mathrm{~cm}^{2}$ dish. Growth medium was changed 15 hours later and protein degradation was measured during the following 6 hours as described in Methods. Curves are fitted by the method of least squares. $0-0,1 \%$ serum, $\mathrm{Y}=0.849+1.078 \times 10^{-3} \mathrm{X}$, $r^{2}=0.92 ; \bullet-\bullet, 4 \%$ serum, $Y=0.832+5.02 \times 10^{-4} X$, $r^{2}=0.92$.

These fitted equations were combined to express directly the correlation between growth rate and protein degradation. The resulting correlations are shown in Figure 6 together with the propagated standard errors of estimate for each curve. These errors are rather large but Figure 6 suggests that the increase in protein degradation rate with decreasing growth rate is smaller in $4 \%$ serum than in $1 \%$ serum, except in cells growing extremely fast. Such a conclusion would also be in accord with the results shown in Figure 3.

\section{DISCUSSION}

Bulk protein in chicken fibroblasts was found to turn over at a rate of 0.8 to $1.9 \%$ per hour, corresponding to half-times of 36 to 86 hours.

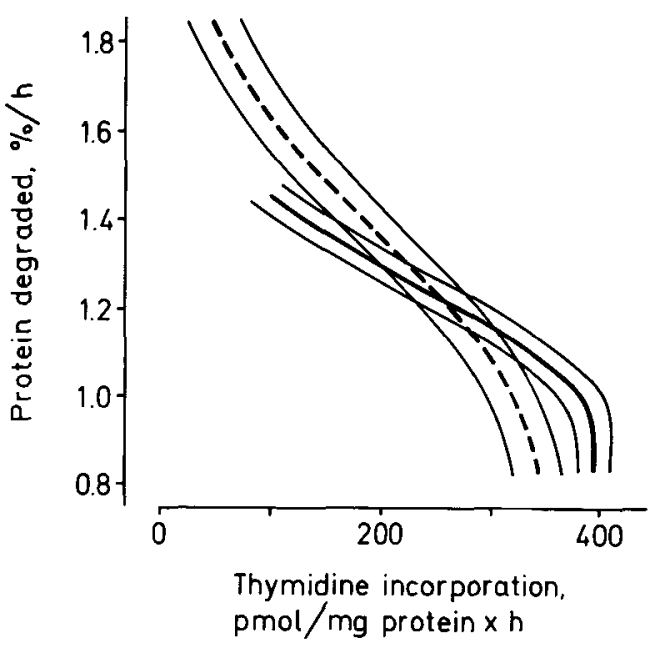

Figure 6. Correlation between thymidine incorporation and protein degradation in chicken fibroblasts.

The regression equations from Figures 5 and 6 were combined to express directly the protein degradation as a function of growth rate (thymidine incorporation), ...-, $1 \%$ serum; - $4 \%$ serum. Thin curves denote propagated standard errors.

These values agree with those reported by WEBER (20) and HENDIL (9).

The rate of protein degradation increases with decreasing cell growth rate when culture density is varied. Our earlier study (9) failed to detect this, probably because we used growth medium with $13 \%$ serum: chicken fibroblasts grown in media with high serum concentrations have incomplete density-dependent regulation of growth (Figure 4 and (16)) so that the difference in growth rate between sparse and dense cultures is larger in media with lower concentrations of serum than in the previously used media with $13 \%$ serum. Also, our data suggest that the magnitude of the enhancement of protein degradation in density-inhibited cultures decreases with increasing concentration of serum in the growth medium (Figures 3,5 and 6). WARBURTON and POOLE (19) showed that there is an inverse correlation between thymidine incorporation and protein degradation in rat embryo fibroblasts whether the concentration of nutrients, growth factors or hormones is varied. We found similar correlations to hold for chick fibroblasts when culture density was varied. 
However, our data suggest that the correlations for cells growing in $1 \%$ and $4 \%$ serum differ. The factors that regulate cell proliferation in culture (nutrients, growth factors, hormones, growth inhibitors, cell spreading etc.) may therefore have differential effects on protein synthesis and protein degradation. Experiments are in progress to examine this with established cell lines which are less variable and allow wider ranges of variation in growth rate than the cells used here.

\section{ACKNOWLEDGEMENTS}

We thank ANNE-MARIE LAURIDSEN for skilled technical assistance and Dr. L.O. SIMONSEN for critically reading the manuscript.

\section{REFERENCES}

1. ADAMS, R.L.P.: Cell culture for biochemists. Elsevier/North Holland (1980)

2. BRADLEY, M.O:: Regulation of protein degradation in normal and transformed human cells. $J$. Biol. Chem. 252, 5310-5315 (1977)

3. CASTOR, L.N.: Responses of protein synthesis and degradation in growth control of WI-38 cells. J. Cell. Physiol. 92, 457-468 (1977)

4. COCKLE. S.M. \& R.T. DEAN: Derangement of regulation of protein degradation in transforming fibroblasts. Bioscience Rep. 2, 107-1 14 (1982)

5. DEAN. R.T. \& S.M. COCKLE: Degradation of intracellular proteins in macrophages and fibroblasts. Acta Biol. Med. German. 40, 1571-1575 (1981)

6. EAGLE. H.: Amino acid metabolism in mammalian cell cultures. Science 130, $432-437$ (1959)

7. Folkman, J. \& A. Moscona: Role of cell shape in growth control. Nature 273, 345-349 (1978)

8. GoldberG, A.L. \& A.C. ST. JoHN: Intracellular protein degradation in mammalian and bacterial cells. Ann. Rev. Biochem. 45, 747-801 (1976)
9. HENDIL. K.B.: Intracellular protein degradation in growing, in density-inhibited, and in serum-restricted fibroblast cultures. J. Cell. Physiol. 92, 353-364 (1977)

10. Hershko. A. \& S. Ciechanover: Mechanisms of intracellular protein breakdown. Ann. Rev. Biochem. 51, 335-364 (1982)

11. HOLLEY. R.W.: Control of growth of mammalian cells in cell cultures. Nature 258, 487-490 (1975)

12. Lockwood. T.D. \& I. A. Minassian: Protein turnover and proliferation. Failure of SV-3T3 cells to increase lysosomal proteinases, increase protein degradation and cease net protein accumulation. Biochem. J. 206, 251-258 (1982)

13. Lockwood, T.D. I.A. Minassian \& L. Roux: Protein turnover and proliferation. Turnover kinetics associated with the elevation of 373-cell acid-proteinase activity and cessation of net protein gain. Biochem. J. 206, 239-249 (1982)

14. Oyama, V.I. \& H. Eagle: Measurement of cell growth in tissue cultures with a phenol reagent. Proc. Soc. Exptl. Biol. Med. 91, 305-307 (1956)

15. RAZ, A. \& A. BEN-ZE'Ev: Growth control and cell spreading: Differential response in preneoplastic and in metastatic cell variants. Int. J. Cancer 29 , $711-715$ (1982)

16. RUBIN. H: Growth regulation in cultures of chick embryo fibroblasts. In: Growth control in cell culture. CIBA Fdn. Symp. G.E!W. Wolstenholme \& J. Knight, eds., Livingstone, Edinburgh and London pp. 127-145 (1971)

17. Siegers, M.P., J.C. Schaer, H. Hirsiger \& R. SCHINDLER: Determination of rates of DNA synthesis in cultured mammalian cell populations. J. Cell Biol. 62, 305-315 (1974)

18. Stoker, M.G.P. \& H. Rubin: Density-dependent inhibition on cell growth in culture. Nature 215 , 171-172 (1967)

19. Warburton. M.J.\& B. PoOle: Effect of medium composition of protein degradation and DNAsynthesis in rat embryo fibroblasts. Proc. Natl. Acad. Sci. USA 74, 2427-2432 (1977)

20. WEBER. M.J.: Ribosomal RNA turnover in contact inhibited cells. Nature New Biol. 235, 58-61 (1972) 